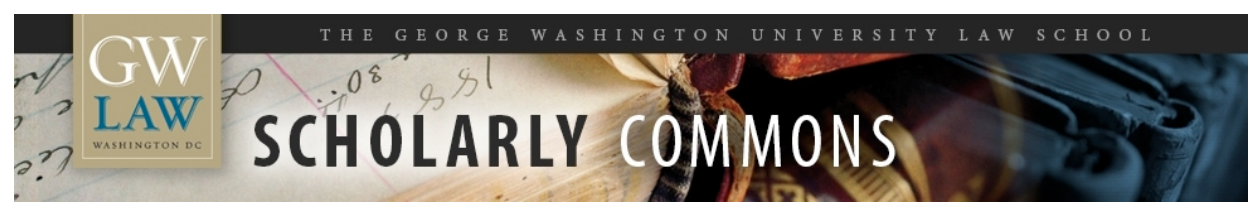

\title{
Unequal Terms: Gender, Power, and the Recreation of Hierarchy
}

Naomi R. Cahn

George Washington University Law School, ncahn@law.gwu.edu

June Carbone

Follow this and additional works at: https://scholarship.law.gwu.edu/faculty_publications

Part of the Law Commons

\section{Recommended Citation}

June Carbone \& Naomi Cahn, Unequal Terms: Gender, Power, and the Recreation of Hierarchy, in 69 STUDIES IN LAW, POLITICS, AND SOCIETY 189 (Austin Sarat ed., 2016).

This Article is brought to you for free and open access by the Faculty Scholarship at Scholarly Commons. It has been accepted for inclusion in GW Law Faculty Publications \& Other Works by an authorized administrator of Scholarly Commons. For more information, please contact spagel@law.gwu.edu. 


\title{
UNEQUAL TERMS: GENDER, POWER, AND THE RECREATION OF HIERARCHY
}

\author{
June Carbone and Naomi Cahn
}

\begin{abstract}
This paper explores the relationship between feminist theory and rising economic inequality. It shows how greater inequality reflects the valorization of the stereotypically male qualities of competition and hierarchy, producing a greater concentration of wealth among a small number of men at the top, shortchanging men more than women through the rest of the economy, and altering the way that men and women match up to each other in the creation of families. By creating a framework for further research on the relationship between the norms of the top and the disadvantages of everyone else in more unequal societies, the paper provides a basis for feminists to develop a new theory of social power.

The paper demonstrates how the development of winner-take-all income hierarchies, the political devaluation of families and communities, and the terms of the family values debate diminish equality and community. The paper addresses how to understand these developments as they affect both the structure of society and the allocation of power within our families in ways that link to the historic concerns of feminist theory.
\end{abstract}

Special Issue: Feminist Legal Theory

Studies in Law, Politics, and Society, Volume 69, 189-220

Copyright (C) 2016 by Emerald Group Publishing Limited

All rights of reproduction in any form reserved

ISSN: 1059-4337/doi:10.1108/S1059-433720160000069008 
It accordingly ends by asking the "woman question" in a new way: one that revisits the stereotypically masculine and feminine and asks how they connect to hierarchy, one that considers whether the inclusion of women changes institutional cultures in predictable ways, and one that wonders whether the values that today are associated with more women than men offer a basis for the reconstruction of society more generally.

Keywords: Feminism; economic inequality; family structure

Modern feminism (and American legal theory more generally) has been slow to respond to an era of increasing economic inequality and the growing dominance of the one-tenth of 1\% (Noah, 2012). The feminist critique of mid-twentieth century America arose during a period of relative income equality, and it focused on gender-based inequality. For a 30 -year period from the mid-1940s through the late 1970s, class differences became less important and white males enjoyed a remarkable period of relative equality among themselves (Goldin \& Margo, 1992). In this context, the routine exclusion of women from many workplaces and racial minorities from full societal participation became impossible to ignore, and once made visible, impossible to justify. Both mainstream legal analysis, which focused more on formal equality, and critical legal theories, which examined systems of power, contributed to the identification and dismantling of the practices that had produced the wholesale exclusion of particular groups from employment, influence or political participation.

The challenge for modern feminism is to explain how women and the critique of patriarchy fit into a new era of inequality, an era that has increased the concentration of overwhelmingly male power - even as a number of journalists (see, e.g., Mundy, 2012; Rosin, 2012) herald the rise of women, accurately pointing out that women's educational achievement now outpaces men's, the overall wage gap has narrowed, and women enjoy similar levels of workforce participation to men. Feminist theory, then and now, reflexively embraces equality and decries hierarchy. Yet, the theories that sought to explain and challenge women's wholesale exclusion from the workplace do not necessarily work to explain women's current places within it, and women's lack of power within the home bears no necessary 
relationship to women's lack of power today in effecting relationships on terms of their choosing.

In this paper, we set out the initial questions for a specifically feminist critique that interrogates the current increase in hierarchy and the resulting inequality. To do so, the paper first considers the gendered nature of changes at the top, middle, and bottom of the income structure, asking the question that has always defined feminist method: what patterns become visible when the focus turns to women's distinctive experiences? ${ }^{1}$ We find that in an era of wage stagnation, the big winners have been those in the top executive ranks, the financial sector, and the most lucrative professions. These winners, who enjoy outsized compensation tied to something other than market compensation for skills, have been disproportionately male, and they have contributed to an increasing gender gap in income for college graduates as a group. In the meantime, the most substantial "progress" over the last 20 years in diminishing the gender pay gap in this country has come from declining male wages among those without a college degree.

Second, the paper ties the economic structure to changes within the family. Marriage has become more, not less, important to the fortunes of men and women at the top of the social order. Two incomes become an important component of middle class life for all but the economic über-elite, and two-parent investment in children continues to pay off in children's social and cognitive development. Yet, the ability to achieve stable relationships and provide resource-intensive caretaking has become a marker of class for reasons tied to the impact of greater hierarchy in society more generally and the persistence of gendered expectations about intimate partnerships.

Finally, the paper argues that all of these developments - the creation of winner-take-all income hierarchies, the political devaluation of families and communities, the terms of the family values debate - reflect the valorization of stereotypical qualities associated with hierarchy and individualism at the expense of equality and community. Dominance games - short term, reductionist, status competitions - are almost always destructive, harmful to women as a group (plus most men), and inimical to the reconstructive project. Understanding where they come from allows us to counter them more effectively.

The question on which we end is how to understand these developments as they affect both the structure of society and the allocation of power within our families in ways that link to the historic concerns of feminist theory with gender-based power and the devaluation of caretaking. We accordingly end by returning to the "woman question" (Bartlett, 1990). In 
doing so, we revisit the stereotypically masculine and feminine and ask how they connect to hierarchy, we consider whether the inclusion of women changes institutional cultures in predictable ways, and we wonder whether the values that today are associated with more women than men offer a basis for the reconstruction of society more generally. We conclude that what feminism needs is an invigorated theory of power that explains the reemergence of steeply banked hierarchies, women's relationship to them, and the failure to move toward a more "supportive state" (Eichner, 2010).

\section{CRITICAL LEGAL ANALYSIS, FEMINISM, AND THE ANALYSIS OF POWER}

The enduring difference between mainstream and critical legal analysis is the issue of power. Mainstream legal analysis, strongly influenced by liberal theory, tends to treat individual decision-making and institutional operation in isolation. It typically (though not invariably) brackets the initial distribution of resources, pays relatively little attention to class, race, and gender, and assumes (rather than interrogates) the capacity for autonomy and free choice. In contrast, critical theory, from Marx onwards, has long made power central to its analysis.

Marx's original analysis after all sought to link the structure of economic power to the disadvantages of the less privileged (see, e.g., Gabaldon, 2013; Testy, 2000), ${ }^{2}$ and the contemporary critiques of inequality link inequality itself to negative consequences for society more generally (Piketty, 2014; Stiglitz, 2012; Wilkinson \& Picket, 2009). Critical theory seeks to identify sources of hierarchy, subordination, and exploitation and to make visible inequalities, such as those between men and women, different sex and same sex couples, and racial and class bias that might otherwise seem natural or inevitable. Within the law, feminist theory and critical race theory have attempted to identify the constraints on individual decision making. They have developed explanations for how systems based on class, race, and gender hierarchies arise and perpetuate themselves. They are sensitive to the role of culture and power in influencing how individual and organizations see themselves, their roles, and their choices.

It is ironic therefore, that in an era of much greater inequality, feminist theory has yet to fully grapple with the role of women in a new, more inegalitarian era. A central reason may be what some have called "the death of sisterhood" (Bennhold, 2013). Elite women focus on the limitations that 
keep them from reaching the pinnacles of societal power (Sandberg, 2013; Slaughter, 2012; Wolf, 2013). Yet, the most trenchant recent accounts of the status of women emphasize how little these efforts have to do with the lot of the majority of women, who have trouble making enough income to sustain their families at all. (Wolf, 2013). Critical theorists, wary of the essentialism of late-twentieth century feminism, distrust any effort to describe women as a monolithic group with shared interests. And the renewed scientific interest in gender differences makes many fear that any discussion of male versus female values or interests will simply empower those inclined to see such differences as a justification for the existing state of affairs. While many feminists, therefore, criticize the growing inequality and certainly challenge the women who seem to benefit from it, a distinctively feminist theory that explains the growth of inequality among men and women, relates it to women's place within society, and proposes comprehensive alternatives has yet to emerge.

The feminism of the 1970s and 1980s articulated a theory of power. Yet, feminist efforts to link the status of women to a theory of patriarchy appear frozen at the time of the classic debate in the 1980s between Catharine MacKinnon and Carol Gilligan (Dubois, Dunlap, Gilligan, MacKinnon, \& Menkel-Meadow, 1985). These divisions in early feminism between MacKinnon versus Gilligan were (at least in part) about defining the terms of patriarchy and women's source of disadvantage versus men's. MacKinnon, in her emphasis on an eroticization of dominance and submission, attempted to construct a theory of hierarchy that explained male power. Carol Gilligan, in her critique of theories of child development, wanted to revalue the stereotypically feminine, identifying an ethic of care with women, and the devaluing of such concerns as an instrument of women's marginalization in the broader society. MacKinnon challenged Gilligan's thesis, arguing that you cannot label these values "hers," when he has "his foot on her throat" (Dubois et al., 1985, pp. 74-75). MacKinnon insisted that the focus should be on the source of male power and that until that power was dismantled, any effort to identify traits or values as authentically those of women was misguided. Gilligan responded that she did not necessarily claim that the prototypically feminine traits she identified were intrinsically associated with women, only that these traits should be valued more highly and that failure to do so worked to women's disadvantage.

Looking back on this debate with light of hindsight emphasizes the ambitions and limitations of late-twentieth century feminism. The sexual violence that MacKinnon saw as central to patriarchy has diminished in its 
ability to exclude women in a wholesale way from the public sphere and, yet, in other respects it remains pervasive. The change in the family and the greater independence of women has led to dramatically lower reports of domestic violence and women, in fact, appear to enjoy substantially greater ability to form families and enter into sexual relationships on a variety of terms (Stevenson \& Wolfers, 2006). Today's feminists are more likely to applaud women's greater sexual freedom than to worry, as MacKinnon, did that it would simply empower more sex on male terms. Yet, although none would claim that either patriarchy or sexual violence have disappeared, ${ }^{3}$ MacKinnon's dominance analysis has not been updated and no other theory linking sex - or gender - and power has emerged in its place. In the meantime, however, even mainstream legal theorists agree that in our new more unequal age, capitalist power has been remade. One key challenge for feminism is to explain how this new era of inequality, which in some ways benefits and in other ways marginalizes women, is different from the patriarchy of the industrial age.

Gilligan's theories, which were subjected to withering critiques in their day to the extent that they assign particular traits or values to women rather than men, survive. Contemporary feminists have incorporated the values underlying the ethic of care into a more general test for a just state rather than as a critique of patriarchy (Eichner, 2010; Fineman, 2010; McClain, 2006; West, 2011). They argue that attention to the vulnerable and those who care for them is critical to societal well-being, not necessarily because these qualities represent either women's authentic values in opposition to those of men or because they constitute a primary barrier to gender equality, but rather because all societies depend on the provision of nurturance and the resilience it encourages (Fineman, 2010). Martha Fineman's vulnerability theory emphasizes the intrinsic vulnerability that comes with childhood, age, and illness, and the societal importance of providing for resilience rather than writing off the more fragile and disadvantaging those who care for them (Fineman, 2010). Joan Williams, in her portrayal of the ideal worker and the limitations of the maternal wall, similarly calls attention to the failure to accommodate those with family responsibilities as full citizens in today's workplaces (Williams, 2010). Linda McClain, Max Eichner, and Robin West complement Fineman and Williams in insisting that the liberal, democratic state depends on the wellbeing of children and that particularly in the face of greater inequality, the state's failure to assume greater responsibility for the preparation of all children impoverishes both the next generation and the society that depends on them (Eichner, 2010; McClain, 2006; West, 2011). 
Taken together, these accounts do not explain the relationship between gender and growing inequality, nor how the remaining barriers to women's advancement fit together with a theory of patriarchy. Indeed, contemporary feminism's reluctance to endorse either MacKinnon's association of patriarchy with the eroticization of dominance and submission or to identify the ethic of care with an explanation of the role of gender in social construction leaves modern feminism without a working description of the role gender plays in a more unequal society.

Ironically, masculinities studies have been much more eager to examine the links. It is here that analysis has turned to the effect of hierarchies among men. Allan Johnson, a sociologist who helped to pioneer masculinity studies, defines "patriarchy" as a male-centered, male-identified, maledominated social structure and maintains that it is male distrust and fear of other men that operates as the core motivating force in the creation of hierarchy (Johnson, 2007, pp. 3-23). Johnson argues that:

\footnotetext{
Patriarchy encourages men to seek security, status, and other rewards through control; to fear other men's ability to control and harm them; and to identify being in control as both their best defense against loss and humiliation and the surest route to what they need and desire. In this sense, although we usually think of patriarchy in terms of the assertion of male power over women, it is also a system that valorizes the creation of hierarchies that give men power over other men. While the oppression of women is certainly an important consequence of patriarchy, it may paradoxically not be the point of patriarchy. (Johnson, 2007, p. 26)
}

Legal scholars have thus begun to examine the impact of greater inequality on men, recognizing that men may be the biggest winners and losers in a more patriarchal society. Nancy Dowd, in particular, has emphasized that at the core of masculinities theory is the recognition that men pay a price for "privilege," that is, for the advantages that come from the ability to construct more steeply banked hierarchies (see Dowd, 2008, p. 248, 2010a, pp. 13-73, 105-123, 2010b, p. 430). Like Johnson, she sees not only patriarchy, but also masculinity, as about the relationship of men to other men at least as much if not more than it is about the relationship of men to women. A man who is relatively well off, and "powerful" with respect to the women in his life, may still feel "powerless" because of his awareness of the other men who have more power than he does (Dowd, 2010b, p. 419).

Dowd shows that men can be both oppressors and victims of the changes produced by greater hierarchy; indeed, Dowd argues that the nature of male hierarchies explains more about the persistence of rigidly defined male roles than discrimination against women by itself (Dowd, 
2010b, p. 419). Within this critique, the question becomes not so much why elite women lose out to men who work 60 hours a week (feminism has long been willing to answer that question), but why men compete among themselves in such terms. Taking this critique further requires consideration of the relationship between the top and the bottom of a more unequal society - and that in turn requires consideration of the reallocation of power.

\section{THE TERMS OF INEQUALITY}

The story of the last 30 years is one dominated by the changes in the way men relate to each other and how this affects the terms of women's engagement both within and outside of the home.

The period from the end of World War II through the mid-1970s has been dubbed "The Great Compression" (Goldin \& Margo, 1992). In this period, which saw the growth of the Civil Rights movement and the first wave of modern feminism, differences among white men, between white collar and blue collar workers, and between North and South, narrowed markedly (Ibid.). Politically, economically, and socially, the commitment to equality reached a level not seen before or since.

The last 30 years, in contrast, have been labeled the "Great Divergence." Increased inequality, which began in the late 1970s and resumed after the financial crisis of 2007, has been spearheaded by the divergence in male incomes. Today, the Gini coefficient is higher for men than for women and it is projected to remain so through at least 2035 (Schwabish \& Topoleski, 2013). The increases in inequality within each race have also been notably greater than interracial differences (Polarized America, 1947-2000). The same is true for children's cognitive achievement and test scores - the changes attributable to income inequality have become much greater than those attributable to racial inequality (Reardon, 2011). Moreover, even within the same broad groups such as white college graduates, income differences have grown and as they have, income has become a bigger factor in children's life chances (Reardon, 2011).

The reemergence of income inequality makes average differences between men and women misleading. Over these years, for example, the composite wage gap between male and female earnings has narrowed. But the composite figures are meaningless. In 1990, for example, the size of the wage gap in earnings did not vary much by education and to the extent it did, college graduate women made a higher percentage of the "male" wage 
than those with less education. By 2007, that relationship had flipped. Looking at all college graduates who are employed full time, the wage gap increased between 1990 and 2008 (Infoplease, 1990-2010). During the same period, it shrank considerably for those without college degrees (Infoplease).The overall narrowing reflects the decline in male blue collar wages, and it cloaks an increase in gender-based disparities for the upper quintile of the population (Carbone \& Cahn, 2013a).

Examining why demonstrates substantial changes in societal power. The jobs that produce the greatest gender-based income disparities are "generally characterized as 'power' and leadership jobs, such as chief executives, education administrators, and finance positions" (Ny, 2013; see Carbone \& Cahn, 2013a). The jobs with the biggest gender gaps on average pay better than those with narrower disparities $(\mathrm{Ny}, 2013)$. In contrast, those positions with the smallest gender differences tend either to be low paying, unskilled positions (stock clerks, packagers, receptionists) or to be skilled staff positions (respiratory therapists, computer support specialists, operations research analysts, medical scientists) ( $\mathrm{Ny}, 2013)$. The former do not pay anyone well; the latter are subject to market competition that keeps the reimbursement for skills, even needed skills in short supply, relatively modest.

The positions that show the greatest growth in overall incomes have occurred in arenas where compensation can be manipulated (Bass, 2012; see also American Association of University Women, 2013, p. 16). The two largest categories are the top executive and financial ranks, which account for a significant portion of all income growth since the 1980s (Mishel, Bernstein, \& Allegretto, 2007; Mishel \& Sabadish, 2012). In 2012, women held only a little over $14 \%$ of the executive officer positions at Fortune 500 companies, and more than $25 \%$ of these companies had no female executive officers. ${ }^{4}$ Researchers find that the increase in executive compensation, unlike increases in professional compensation (think engineers, pharmacists), is not market driven and does not reflect productivity (Belsie). The outside directors for Corporation A may vote to raise the compensation of Corporation A's executives, and then go home and ask the board of their own corporation for a raise to match the one they just voted for someone else. To the extent that the board requires external measures of validity, the executives may take a substantial portion of their pay in the form of stock options. This in turn increases the pressure to produce short-term increases in earnings, increases that they can produce by layoffs, shortchanging pension funds, cutting investment in employee training or tenure, and other measures that may or may not be in the company's (and certainly not 
the employees') long-term interests (Dallas, 2012, p. 316). A 2013 study further indicates that these increases in executive pay, and particularly the role of stock options, can and have been manipulated, and that the manipulation affects income inequality both by increasing gains at the top and affecting the well-being of everyone else (Bivens \& Mishel, 2013).

A parallel pattern characterizes the financial sector. The six job categories with the largest gender gap in pay and at least 10,000 men and 10,000 women were in the Wall Street-heavy financial sector: insurance agents, managers, clerks, securities sales agents, personal advisers, and other specialists (Bass, 2012). Moreover, while the percentage of women in business schools has increased to almost $50 \%$, the number of women on Wall Street has dropped off since 2000. And in 2008 and 2009, the number of sexual harassment charges per woman in the financial industry grew higher than in previous years (Eichler, 2012).

Within the professions, women have done well overall while still losing ground in the most lucrative positions. Among lawyers, for example, gender-based differences in entry level positions are relatively small, but as firms have moved toward greater differentiation among equity partners based on rain-making performance, the gap between men and women partners has increased (Flom \& Scharf, 2011, p. 5). Among doctors, the gender gap in pay has inexplicably widened in starting salaries, even after controlling for specialty, education, and hours worked (Lo Sasso, Richards, Chou, \& Gerber, 2011, pp. 193-196).

In reviewing the causes of gender-based differences in compensation, an AAUW report commented that "[t]he U.S. economy is characterized by "masculine" values of competition and individual achievement" (American Association of University Women, 2013, p. 7). Whether such values describe the economy as a whole, they increasingly characterize the most lucrative positions: the top management ranks, companies with rank and yank merit pay systems, the financial sector, corporate law firms, top medical specialties, and even universities, where the gaps between top administrators and senior faculty, grant producing research scientists, and other faculties have grown. ${ }^{5}$ And this is true despite the absence of evidence either that these changes have improved corporate performance or that these qualities identify better business leadership. ${ }^{6}$ Feminists, of course, have long decried the excessive emphasis on the "masculine" values of competition and individual achievement, but these data indicate that the emphasis on high stakes competition has increased substantially at the top income levels over the last 30 years, and women, who have otherwise gained in the economy as a whole, have lost ground where increasing 
rewards go only to the select few (see, e.g., Lipsitz, 2013). Indeed, one significant factor in the gender pay gap is the nonlinear relationship between earnings and hours; "a flexible schedule often comes at a high price" (Goldin, 2014, p. 27) and competition to put in long hours is particularly intense in the corporate and financial sectors that have experienced the greatest income growth (Bertrand, Goldin, \& Katz, 2008, pp. 3-4).

The disproportionate rewards for the few, the emphasis on short-term earnings measures, and the more competitive nature of corporate management have contributed to the hollowing out of the center of the economy in ways that disproportionately affect men. The two groups who have perhaps lost most are relatively high-paid blue collar workers, including both the skilled and unskilled, and disproportionately male middle managers. At one time, both groups might have started work for a given company shortly after completing formal education, and received training and regular promotions on the job, staying with the same company through retirement with secure pensions and health benefits ${ }^{7}$ (see generally Kalleberg, 2011). Today, in contrast, blue collar employment both pays less and has become less stable and companies have reduced the middle management ranks, outsourcing more of their work to independent contractors at home and abroad, who absorb the costs of benefits and the ups and downs of the business cycle. ${ }^{8}$ While the increased number of small businesses has taken up some of the slack, the result for both groups is less stable employment, a weakened web of health care, retirement, and unemployment benefits, lower net earnings and a declining share of productivity gains going to labor rather than capital $^{9}$ (Kalleberg, 2011, p. 93).

Over the course of this 30 plus year period, levels of societal inequality have risen back to highs last reached at the height of the Gilded Age and the Great Depression (Noah, 2010).${ }^{10}$ The "Great Recession" that followed the financial crisis of 2008 has only made things worse. The New York Times reported in October 2012 that income inequality had soared and the top $1 \%$ of earners reaped a stunning $93 \%$ of the income gains in the first full year of the recovery from the 2008 crisis (Rattner, 2012). In the meantime, the wages of the bottom 90\% fell between 2009 and 2011 (Mishel \& Finio, 2013).

Political changes compound the growing income inequality. As political scientists Jacob Hacker and Paul Pierson explain in Winner Take All Politics, growing income inequality is not the inevitable product of capitalism (Hacker \& Pierson, 2010). Instead, a political system has reflected policies favoring the economic elite, including lower taxes at the top, fewer regulations, less enforcement, the evisceration of worker protections, and 
the erosion of the minimum wage (Hacker \& Pierson, 2010, pp. 54-72; see also Lioz, 2013). Taken together, they undermine worker ability to form collective units while strengthening management ability to circumvent the control that might arise from either greater employee rights or regulatory scrutiny.

Studies of income inequality show the class and gender impact of these political changes. First, the erosion of the minimum wage has had the greatest impact on the position of working women at the bottom of the economic ladder, increasing the disparities between the 50th and 10th percentile of female income (Belsie). Second, the decline in unionization, spurred in part by hostile legislation, accounts for $14 \%$ of the increase in variance in male wages between 1973 and 2001 (Belsie). These changes, which reduce wages, working conditions, and employment stability, have contributed to a large-scale reduction in labor force participation, and disproportionately affect men (Belsie). The decrease in the permanence of employment and the declining share of corporate earnings that go to workers either through wages or through taxes and public benefits is at the core of the changes in the American economy and the American family.

\section{THE RIPPLE EFFECTS: THE IMPACT OF STRUCTURAL POWER ON FAMILY RELATIONSHIPS}

The impact of greater societal inequality - and the corresponding concentration of resources at the top - is not simply a matter of differential pay in the senior management ranks. It has ripple effects throughout society. Some of the impact comes from long-term changes in the way that men and women match up with each other. Greater hierarchy has reinforced the importance of male status as an asset in marriage markets and reinforced gendered roles at the top, creating powerful opposition to remaking the family on terms that might provide more support for non-elite families.

While greater male inequality increases the concentration of men at the top and bottom of male status hierarchies, women remain more concentrated in the middle seeking to pair with a smaller group of comparable men (see Carbone \& Cahn, 2014). Ironically, women in the center of the economy have gained in income, workforce participation and the ability to raise families on their own compared to the women of a half century ago, while the men outside of the elite have lost ground in comparison with the men of a half century ago. Women's advances, however, do not necessarily 
translate into either greater societal power or greater power within individual relationships because of the corresponding increase in the power of elite males. Instead, the gender mismatch produces class-based differences in family formation that give well-off women influence primarily within relatively traditional marriages and make it increasingly difficult for other women to form stable relationships at all (see Carbone \& Cahn, 2013b, 2014). These effects on the family magnify both the changing role of gender and the role of inequality in skewing the life chances of the next generation of children.

The impact of growing inequality on the family comes from the intersection of three long-term societal changes. First, the sexual revolution and the women's movement that began a half century ago have increased women's independence. These changes occurred during the same period as the shift from a manufacturing economy to one with greater job growth in the service sector. ${ }^{11}$ The growth in the service sector produces greater demand for the types of services women have traditionally performed and indeed, women's employment expanded more in the traditionally female service sector than in historically male sectors such as manufacturing (see, e.g., Rendall, 2011). Women's greater workforce participation, in turn, has increased women's ability to go it alone in living on their own and raising children. This allows them greater freedom to say no to less attractive relationships (see, e.g., Stevenson \& Wolfers, 2006, p. 269). Feminist philosopher Susan Moller Okin emphasized the importance of "exit," that is of the ability to leave an unsatisfactory relationship, in determining the power dynamic in the family (Okin, 1989). There is no question that women as a group, who initiate the vast majority of divorces, have gained in their relatively greater independence from men (see, e.g., Baum, 2007, p. 48).

The second is the impact of greater inequality on relationship markets. Greater inequality segments marriage markets (college graduates have become more likely to marry each other), writes off a high percentage of men at the bottom of the social order, and skews the ratio of men to women within each market (Carbone \& Cahn, 2014).

The third is the role of male societal power in determining not just the number of potential partners within each class-based marriage market, but also how the skewed sex ratios affect the terms of relationships. Women may enjoy greater independence but they do not necessarily enjoy greater power within relationships commensurate with their increase in the ability to go it alone.

To explain the interaction of these factors, we turn to the classic work on work on sex ratios by sociologists Marcia Guttentag and Paul Secord. 
In an influential book in the 1980s, Guttentag and Secord described what they termed "structural" or societal power and "dyadic" power or power to choose relationships (Guttentag \& Secord, 1983, pp. 24-27). They observed that sex ratios, that is, the ratio of men to women, affect the ability of men and women to enter into relationships in terms of their choosing. If men outnumber women, women have a greater choice of available men. If women outnumber men in a given marriage market, in contrast, the men can more easily chose among possible partners or end one relationship and find another. Sex ratios, like other factors that affect supply and demand, accordingly affect relationship "price" and thus bargaining power to set relationship parameters.

The sociologists added, however, that the specific ways that changing sex ratios affected dyadic power, or relationship bargains, depended on who exercised structural power in the society in which the changes took place. A high number of men in comparison with the available women should make women more valuable, but women only control that increase in value if they have structural power. At a time in nineteenth-century America, for example, when Chinese men outnumbered Chinese women by a 20:1 ratio, Chinese criminal gangs or "tongs" forbade their prostitutes from marrying, and treated the men who tried to woo them as thieves (Guttentag \& Secord, 1983, pp. 29-30). Scarcity increases value only for the "owner" of the asset.

Even in less extreme cases, scarcity tends to increase male interest in controlling sexual access to women, but it does not necessarily give women themselves more influence. The authors cite the dramatic example of Orthodox Jews in Eastern Europe, where boys significantly outnumbered girls (Guttentag \& Secord, 1983, p. 85). Guttentag and Secord argue that the high sex ratios in a patriarchal society produced a reinforcing set of practices. When women are scarce, men commit to marriage and divorce rates fall. With stable marriages, the parents (and particularly fathers) invest more in their children and, indeed, Orthodox communities in Europe and the United States had lower infant mortality rates than other communities even when they were desperately poor. The high level of parental investment helped to maintain strict religious practices, which in turn reinforced family stability. The women, though highly valued, did not enjoy much autonomy.

Guttentag and Secord further maintained that societies in which men have structural power but women outnumber men produce a different set of reinforcing practices. In these societies, the men, who enjoy easier access to women, become less likely to commit to any one person, and more likely 
to play the field (regardless of the promises they may have made initially). The women become more distrustful of the men. They invest more in their own earning capacity, and become more financially independent, less likely to marry, more likely to divorce, and more likely to have and raise children on their own ${ }^{12}$ (Guttentag \& Secord, 1983, p. 190). Women in these societies do enjoy more sexual freedom, but they again lose out on their ability to influence the terms of the relationships they enter.

Sociologists have attempted to test Guttentag and Secord's theories. They largely find correlations between the sex ratio predictions and observed behavior across a variety of cultures, though with more robust findings in the developed than the developing world (see, e.g., Angrist, 2002, p. 1033; South \& Trent, 1988, p. 1112). In one study, evolutionary psychologists compared different countries in an effort to determine the role of gender in the response to the scarcity of the opposite sex. They asked the question, when men become scarce, will the men, like women in similar circumstances, become pickier about potential mates or will they instead take advantage of the increased supply to play the field, given the lower price of sexual access? The survey found, in accordance with Guttentag and Secord's predictions, that men preferred more relationships to higher quality partners and that what changed most in response to male scarcity was the women's attitudes. They became less likely to marry and their standards for an acceptable husband increased (Stone, Shackelford, \& Buss, 2007, p. 294). The researchers concluded, in other words, that when women outnumber men within a particular relationship market, men become cads. They can enjoy multiple relationships and they do. If women will still have them with their faults, they marry. Otherwise, they don't, enjoying their continued access to new mates. Women become jaded by the men's behavior and they, too, become more reluctant to commit to a longterm relationship. The result tends to be a cultural shift toward greater promiscuity, more gender distrust, greater investment in women's income opportunities and less in men's, and fewer stable long-term relationships.

Applying these predictions to American society offers a theory that corresponds to the diverging patterns in American families (although it does not explain why men have more structural power). At the top of the American income ladder, male high earners outnumber the comparable women and marriages have become more stable. ${ }^{13}$ And family law has shifted to provide the men at the top greater control over their children and less obligation to continue to share their higher incomes with former spouses after a breakup (Carbone \& Cahn, 2014). In the middle and the bottom, marriage is becoming more fragile or disappearing altogether 
(see McLanahan, 2004; Wilcox \& Marquardt, 2010, p. 23, fig. 5). Marriage to an unreliable partner has become a particularly poor deal for lower income women (Carbone \& Cahn, 2014). At a time of declining marriage rates, the only group in society whose marriage rates have increased is the top $5 \%$ of women defined by income; the top $10 \%$ have marriage rates that have held steady. These women, taken together with the comparable group of men, constitute the societal sector where gender-based income differences have grown most markedly and where highly paid men are most likely to outnumber and outearn highly paid women (Greenstone \& Looney, 2012).

While the effects are not as dramatic, the emphasis on marriage has increased for the larger group of college graduates as a whole. Indeed, college graduates collectively display many of the characteristics Guttentag and Secord associate with high sex ratio societies in which men outnumber women: the divorce rate has fallen substantially since 1990 even as it has increased for the rest of society, the non-marital birth rate, as least among whites, has remained low, and the likelihood that the children of college graduate parents would be raised in a two-parent home increased between 1982 and 2006 for both whites and African-Americans (see McLanahan, 2004; Wilcox \& Marquardt, 2010, p. 23, fig. 5). Sociologists have predicted that as women outnumber men on college campuses, the opposite should have occurred and there is in fact some evidence that college gender ratios affect the terms of sex on campus (Regenerus \& Uecker, 2011, p. 122). But, with respect to family formation, college graduates, particularly whites and Asians, simply replicate the class-based gender divisions in the rest of society.

First, the much-heralded gender gap in college attendance turns out to be a class and racial gap. Overall, the gender-based differences in college attendance are much smaller for the group entering college shortly after high-school graduation than for the group returning to school later in life. Among this younger group, there is no gender gap for the top quarter of households by income: males make up $51 \%$ of the children entering college from these families ${ }^{14}$ (King, 2010). For the same income group among African-Americans, the numbers fluctuate more, rising from only $41 \%$ male in the mid-1990s to 54\% male in 2003-2004 and then back down to $48 \%$ in 2007-2008. Among whites, the biggest recent drop in male attendance has come from households in the bottom income quartile and, indeed, for that group males make up only $43 \%$ of the total. The percentage is even lower for African-Americans, ${ }^{15}$ with the drop occurring substantially before the similar drop for whites (see Marklein, 2005). 
Second, the likelihood that a collage graduate will marry and that he or she will marry someone with the same education turns out to vary by class. The more advantaged the college graduate, the more likely he or she is to marry and to marry a fellow college graduate (Musick, Brand, \& Davis, 2012). These figures may be skewed by the fact that women from less advantaged backgrounds may be more likely to attend college later in life, and at that time in their lives, they may either be married already or they may not match up well with what tends to be younger male students.

Third, race further affects the result. The gender-based disparities in attendance are greater for African-Americans and Latinos, even controlling for class (King, 2010; see also Banks, 2011). Moreover, male minority college graduates do not enjoy as great an income advantage over minority women graduates as do white male college grads (Carbone \& Cahn, 2014) and the geographic distribution may be different - the most successful minority women are more concentrated and more likely to outnumber the comparable men in major metropolitan areas (see American Association of University Women, 2013; Cohen, 2010; U.S. Census Bureau, 2009).

Finally, the income distribution of male and female college graduates makes it more likely that men will earn more. As we mentioned above, the gendered wage gap has grown for college graduates as a group since 1990, and even looking just at those between 25 and 34, men's median income is greater than women's and men outnumber women in the income ranks above $\$ 100,000$ per year by more than two-to-one (see American Association of University Women, 2013; Cohen, 2010; U.S. Census Bureau, 2009). Further, more than half of the women college graduates who marry non-grads marry men who earn more than they do (Cohen, 2013).

Putting these factors together explains the continued emphasis on marriage for the top women in society and why college graduates as a group experience different family patterns from those without degrees. College graduate women have enjoyed greater overall increases in income than other women, but their increases have lagged behind those of comparable men. The women in this group, on the whole, can and do find men worth marrying and their relationships have become more stable since 1990 than they were in the more turbulent 1970s and early 1980s (McLanahan, 2004). Yet, without greater societal power, the women in these relationships do not necessarily share equally in the benefits, a phenomenon that is painfully visible at divorce. As women have gained greater ability to leave relationships, both because of no-fault divorce and because of their greater income, family law has also changed. It places less emphasis on post-divorce financial obligations, which have historically benefitted women, and more on 
shared parental obligations - which overwhelmingly benefit men (see, e.g., Brinig \& Allen, 2000, pp. 128, 136-137, table 1). Some of these changes undoubtedly reflect fathers' growing involvement in childrearing, but women still spend more time in child care than men. A University of Wisconsin study also found that although sole maternal custody had declined for all groups, the ability to exercise custodial rights reflects the father's income. Married men enjoy a greater likelihood of a shared custodial order than men who establish paternity in other ways, and greater male income correlates inversely with the likelihood that mothers will enjoy sole custody (Brown \& Cook, 2012, pp. 28-29). Overall, the net effect is greater parental investment in children among those with more advantages, but not necessarily greater female power within relationships commensurate with women's increased independence (see Carbone \& Cahn, 2014).

For those without college degrees, the decline of relationship stability is closely tied to the combination of men's declining employment prospects and the persistence of gendered norms. Men who are struggling to find work or who have a comparatively low potential for breadwinning are less likely to get married (Bianchi, 2011, p. 26). In a given marriage market, if a randomly chosen woman becomes more likely to earn more than a randomly chosen man, marriage rates decline (Bertrand, Kamenica, \& Pan, 2013, p. 4). Moreover, a wife is more likely to cut back on her hours if the additional income would exceed her husband's (Bertrand et al., 2013, pp. 23-24). Indeed, over the last 10 years, low-income whites increased their support for a traditional gendered family model while support continued to fall for high-income couples (Murray, 2012, p. 151). Yet, the likelihood that the wife earns more than the husband corresponds to class. In families with dual earners, the wife earns more than the husband in $70 \%$ of marriages in the bottom quintile of families in comparison with $34 \%$ of wives in families with incomes in the top $20 \%$ (Glynn, 2012). Sociologist Paul Amato and his co-authors find that dual incomes among the better educated correspond to greater marital satisfaction, but dual incomes among the working class do not. Women are more likely to work because their families need the money while they would prefer to spend more time on home and children; those who work because their husband fails to live up to the provider role are among the most divorce prone (Amato, Booth, Johnson, \& Rogers, 2007). Compounding the effects are male reactions to the layoffs that disproportionately affect men without college degrees. Newsweek, relying on the American Time Use Survey, reported that "laidoff men tend to do less - not more - housework, eating up their extra hours snacking, sleeping and channel surfing (which might be why 
the Cartoon Network, whose audience has grown by $10 \%$ during the downturn, was running more ads for refrigerator repair school)" (Dokoupil, 2010, p. 50).

This creates a no-win situation for women. The successful women are better able to find similarly - or more - successful men, but once they marry, the men in their lives tend to enjoy the greater power that comes from a higher income. Less advantaged women, in contrast, enjoy less ability to create stable relationships, to find family-friendly employment (see Williams \& Boushey, 2010), or to exert political power (see Bartels, 2008). But they do enjoy greater autonomy in their direction of their children's lives. Edin and Nelson observe that "[i]n a startling reversal of the way gender typically operates in American society, unwed childbearing seems to offer mom, and not dad, all the power: 'it's her way or the highway,' in the words of one father" (Edin \& Nelson, 2013, p. 214). These results further skew the effects of greater inequality as the top group replicates its advantages through greater investment in children, greater access to education, income and power, and greater ability to insure the dominance of its sons - a small number of whom will be the dominant players in the power structure they have created (Reardon, 2011). Understanding the impact of sex ratios on dyadic power, and the corresponding relationship of family structure with economic inequality does not, however, explain the more fundamental problem of male structural power.

\section{WINNER TAKE ALL POWER DYNAMICS AND THE IMPACT ON GENDER EQUALITY}

Both the increase in structural inequality, which creates more steeply banked hierarchies, and the persistence of gendered notions of dyadic relationships, as they influence family norms, recreate the power dynamics that have long been central to critical theory. These ideas about the nature of competition, fear, dominance, and oppression are not limited to critical theory. Francis Fukuyama, in The End of History and the Last Man, for example (Fukuyama, 1992), argued that the factor compelling ultimate acceptance of liberal democracies and free markets was the desire for recognition; that is, the desire of each person, including slaves and peasants, for a measure of freedom and recognition, and that such recognition could only come from the limits on the power of elites that occur in liberal democracies. In contrast, more steeply banked hierarchies - and 
the emergence of the ultra-successful (think billionaires) or ultra-dominant (think autocrats) - tend to increase the insecurities of even the relatively successful or relatively powerful.

The insecurity that higher stakes competition produces tends to undercut social solidarity (Hayes, 2012). Insecure elites devote more resources, for example, to zero sum status competitions such as ensuring their children's entry into top schools, and express less concern about the increasingly exclusive nature of such institutions. Increasing the stakes of competition increases the incentive to cheat and to use success to rig the game to ensure continued success. Stiglitz (2013) concludes that greater inequality undermines trust for good reasons.

The nature of competition itself may accordingly increase feelings of insecurity in both the successful and the unsuccessful, which in turn may increase the feelings of just dessert among the successful and opposition by both to greater assistance for those on the losing end of the changes (see, e.g., Page, Bartels, \& Seawright, 2013). Such measures, however, which include greater support for public education, assistance for children, restraints on employers such as mandated family leave, and measures to restrain and police the terms of competition, provide the foundation, not just for reducing the impact of today's inequality, but for greater gender equality and greater support for families (see, e.g., Eichner, 2010; Fineman, 2010). The challenge for critical theory should accordingly be to explain the failure to move toward these solutions.

The ability to develop such an explanation requires integrating the core of modern feminism - the woman question - with theories of economic inequality. Asking the woman question to explore these changes in the nature of power and society requires more than filling in a scorecard on the status of women. It requires reconsideration of the values that influence these developments. In an era where women have achieved formal legal equality in the workplace and in the family, the question is no longer the impact of patriarchal power on women but why patriarchal power endures. Central to that analysis is the role of the so-called masculine values of competition and individualism and the greater hierarchy and inequality they produce.

One way of addressing the issue is to ask about the so-called feminine value preferences: can they flourish? Feminine values fit on the more liberal side of the ideological divide that today characterizes American politics (see, e.g., Jost, 2006, p. 654), ${ }^{16}$ so could have a profound impact on policies. Women and men do not, social scientists have found, describe themselves differently in party terms (e.g., Republican vs. Democrat), which often 
reflect upbringing or community. Nor are there long-term differences in the embrace of "conservative" versus "liberal" political identities. ${ }^{17}$ Researchers do, however, find long-term gender variations in attitudes toward equality. Men are more supportive than women of "hierarchy-enhancing" policies, such as military spending or arrests of the homeless for sleeping in public places. Women are also less likely than men to embrace ideologies that maintain that some people are not as good as others or to promote class, ethnic, national or sexual hierarchies. Psychologists have done cross-country comparisons, finding gender differences in the support for statements such as "God made poor people poor" or "some people are just more worthy than others" (Sidanius \& Pratto, 1999; Stanford News Service, 1996). Similarly, on average, women are more likely than men to support "hierarchy attenuating" policies, such as government-sponsored health care, guaranteed jobs for all or greater aid to poor children. Women are more likely to agree that " $[\mathrm{g}]$ overnment should guarantee everyone enough to eat and a place to sleep" than are men (Pew Research Center for People and the Press, 2012). These basic orientations toward equality or hierarchy help explain political attitudes in ways that go beyond narrow interests or the self-labels that pollsters often ask those they survey to select for themselves.

Studies of behavior, as opposed to the thought process that leads to ideological commitment, find similar gender-based patterns. Male and female management styles tend to be different, and female styles tend to be more attentive to group cohesion. Moreover, women are less likely to promote one method to the exclusion of others; instead, they more typically combine multiple approaches in transformational leadership (e.g., Eagly, 2013; Eagly et al., 2009; Shipman \& Kay, 2009). Studies of international development further find that giving women greater say in the distribution of resources produces better results for reasons linked to women's greater inclination to take into account the interests of others (see Desai \& Johnson, 2005, pp. 55-56; Kristof \& WuDunn, 2009; Ni Aolain, Haynes, \& Cahn, 2011, chapter 11; Smith, Ramakrishnan, Ndiaye, Haddad, \& Martorell, 2003, p. 22; Unicef, 2007, pp. 23-24). The 2001 World Bank Report (Mason \& King, 2001) found, for example, that when international aid was distributed to fathers, they often spent the money on themselves in ways that increased the likelihood they would father more children. When the aid was distributed to mothers, they were more likely to spend it in ways that benefited their existing children (Mason \& King, 2001). The problem with today's corporate managers, as indicated above, is that they advance their own interests, rather than those of the community: they divert resources to short-term status competitions that 
enhance individual bonuses at the expense of long-term institutional health. Women typically "invest a higher proportion of their earnings in their families and communities than men" (OECD, 2010, p. 5).

The question for contemporary feminism is what to do with these findings. Critical theorists - and, indeed, all serious scholars - are understandably wary not only of "essentialism" (treating all women alike), but of the overcategorization and oversimplification that comes from reductionist statements that link women generally to any simple category like support for equality (West, 1999, pp. 10-21; see, e.g., Harris, 1990). ${ }^{18}$ These differences, after all, are statistical ones; they indicate that women as a group have somewhat different preferences from men as a group for certain policies, and they do not get to the sources of, and reasons for, these differences. Yet, they do raise the question of what full consideration of women's preferences and women's values, whatever their origins, would add to contemporary theory and how it might contribute to creating a new political and social coalition more committed to equality (Eichner, 2001). Pulling these factors together sets the stage for what Becker (1999) has called a "substantive" feminism.

Feminism begins with asking the "woman" question. Masculinities studies ask the "man" question. A "substantive feminism" - and substantive masculinities - must ask the "human question," without examining men or women in isolation from each other. We should ask not just who or what has been excluded, but how they have been excluded and how to include them with the goal of building on earlier theories of power. Using this approach identifies the problems with patriarchy as not solely rule by men in and of itself. Instead, the problem with patriarchy is that it is an ideological system that valorizes the desire for dominance - the dominance of other men as well as women. The feminist and masculinities critiques of hierarchy share a description of the harmful effects of the desire for dominance.

A substantive feminism together with a substantive theory of masculinities would not be content to denounce all forms of inequality. Instead, it would focus on the destructive aspects of hierarchy linked to a patriarchal system, and the reconstructive project of creating a more inclusive society. These destructive qualities include:

(1) The creation of outsized rewards and steeply banked hierarchies that cannot be justified in terms of either a competitive market or proven benefits;

(2) The celebration of unrestrained competition that increases insecurity and undermines community; 
(3) The failure to recognize and restrain the cheating and rigging that such systems incentivize;

(4) The denigration and dismissal of large segments of the population as unsuccessful and unworthy; and

(5) The marginalization of the care work associated with women and families.

Identifying the destructive qualities of such a system contributes to the identification of a countervailing set of objectives. These objectives include full inclusion in society, attention to the needs of the dependent and the neglected, greater concern for institutions rather than individuals, and emphasis on creating stronger communities (Eichner, 2010; Fineman, 2010).

While a reinvigorated substantive feminism would consider women's' role in encouraging such an agenda, it would not simply replicate calls for greater inclusion of women in decision-making positions. The earlier emphasis on civil rights - and on affirmative action in insuring the greater inclusion of women and minorities - was designed to redress discrimination and the wholesale exclusion of women and minorities from more desirable positions. A reinvigorated feminism would move away from a simplified description of oppressors and victims and from a focus on remedial measures. Instead, it would ask what is necessary to promote the construction of a better society for both men and women, where structural and dyadic power are shared and how to break down the barriers to moving toward that society.

\section{CONCLUSION}

A renewed feminist agenda should accordingly ask the gender question to challenge the sources of increased inequality and to lay the foundation for the formative process that modern feminism has already embraced. The elite of our new gilded age valorizes competition, individualism and hierarchy to disadvantage all but the most elite women and the majority of men; the increasing hierarchy among men and among women in turn remakes relationships among and between men and women. The hierarchies rewarding competition at the top create vicious cycles that block more substantive change. The feminism of the 1970s and 1980s used the woman question to ask how such factors excluded or marginalized women; today, we need to ask the gender question to determine how prototypically male values 
undermine communities and marginalize the majority of individuals. Feminists should storm these barriers as we seek to develop a healthier society that insists the benefits of technological advances and increased efficiency are shared more broadly, creating stronger institutions, more equal communities and greater investment in all of our children. Ultimately, what feminism needs today is a new theory of power that explains the reemergence of steeply banked hierarchies and women's relationship to them. To develop this theory, we need to ask:

What measures are effective in restraining destructive competition without eliminating harmless or productive competition?

What are the most effective ways to limit the ability of a small number of winners to dominate and disadvantage others?

How should we ensure that the fruits of increased productivity, innovation and growth are broadly shared rather than concentrated in the hands of the few?

How do we strengthen institutions, create jobs, and encourage broad based inclusion in the benefits of a prosperous society?

How can we change workplaces to make them family-friendly and supportive for men and women, and why have we not yet succeeded?

How do we protect our children from the increasingly destructive effects of a class-based system of family structures, in which the children at the top are increasingly likely to remain there, while children at the bottom have few expectations of change?

These questions frame the appropriate challenge to the patriarchal roots underlying the growing inequality in American society. Only by seeking to resolve these questions can we create a renewed vision of human society that provides for an egalitarian balance among, and between, men and women (Fineman, 2010).

\section{NOTES}

1. Indeed, feminist method has been defined in terms of asking the "woman question" in order to "challenge existing structures of power ... identifying and challenging those elements of existing legal doctrine that leave out or disadvantage women and members of other excluded groups" (Bartlett, 1990, pp. 830-831).

2. In addition, the most recent critiques of inequality link the structure of corporate governance to the disadvantages to the weakening position of workers. See, for example, Carbone and Cahn (2014). 
3. Indeed, MacKinnon's type of Marxian analysis tends to be skeptical of evolutionary reforms, claiming that without a transformation of the entire dynamic of power relationships, genuine equality is impossible. For a summary of this perspective and its critics, see Kelly (2009, p. 122) and Rorty (1998, p. 7).

4. "In 2012, women held $14.3 \%$ of Executive Officer positions at Fortune 500 companies and $8.1 \%$ of Executive Officer top earner positions. In both 2011 and 2012, one-fifth of companies had $25 \%$ or more women Executive Officers, yet more than one-quarter had no women" (Soares, Bonaparte, Campbell, Margolin, \& Spencer, 2012, p. 1; see Sandberg, 2013, p. 5).

5. One of the consequences of these shifts is greater emphasis on individual advancement than institutional loyalty. The fact, for example, that executive tenure has declined as executive pay has increased is a symptom of these changes. See Lublin (2005), Kaplan and Minton (2008, pp. 2-3); see more generally Dallas (2012), on the greater short-term focus of corporate executives.

6. Indeed, some studies find that women make better business leaders. See Bart and McQueen (2013) and Joy, Carter, Wagener, and Narayanan (2007).

7. Executive tenure has declined as executive pay has increased as well. See Lublin (2005) and Kaplan and Minton (2008, pp. 2-3): "There is some evidence that the increases in turnover and turnover-performance sensitivity are related to increases in block shareholder ownership, board independence, and SarbanesOxley."

8. Indeed, male workforce participation rates overall have reached all time lows. See Hooda (2012).

9. For the change in employment patterns, particularly for white males without a college degree, see Murray (2012, pp. 175-176).

10. Noah observes that a "more authoritative subsequent calculation puts the figure slightly higher, at about 18 percent."

11. "Goods production supplied about three-fifths of economic output in 1950 and about half of its jobs. By 2010, growth in the service sector accounted for twothirds of output and seven out of every 10 jobs." Tankersley (2013).

12. For a modern example, see Mechoulan (2011), concluding that high rates of black male incarceration have increased African-American women's educational achievement and employment rates.

13. See data cited above and a more extended discussion in Carbone and Cahn (2014).

14. Class disparities have an effect on male performance in high school as well as on college attendance and completion. See DiPrete and Buchman (2013, p. 23), suggesting that part of the reason boys do worse than girls is that their performance depends more on school and community reinforcement; both boys and girls do better in better schools, but the impact of better schools on boys is greater.

15. For updated statistics, which indicate that the gender gap in education has levelled off since 2000, and remains largely class based, see King (2010), finding that in 2007-2008, for Blacks, the male percentage of children attending college was $48 \%$, down from $54 \%$ in 2004 (but still up from $41 \%$ in 1995), for Hispanics, it was $48 \%$, down from $51 \%$ in 2004 , and for Asians it was $52 \%$, down from $54 \%$ in 2004. 
16. Jost (2006) stated that:

Conservatives consider people to be inherently unequal and due unequal rewards; liberals are equalitarian. Conservatives venerate tradition and - most of all-order and authority; liberals believe planned change brings the possibility of improvement (Jost, 2006, p. 654).

17. Alford, Funk, and Hibbing (2005), whose twin study indicated that conservative versus liberal beliefs may be influenced by genetic predispositions, nonetheless found that party and religious identification tended to reflect upbringing more than basic orientations toward values such as hierarchy versus equality.

18. Harris (1990) argued that both dominance feminism, as exemplified in Catharine MacKinnon's work, and cultural feminism, as exemplified in Robin West's work, essentialize women's experiences in ways that obscure differences such as race and class.

\section{ACKNOWLEDGMENTS}

We appreciate the extensive comments from Maxine Eichner and our anonymous reviewers, and the editorial work of Max, Clare Huntington and Austin Sarat. Thanks to Jessica Qian and Jodi LeBolt for research assistance. We also thank Brian Bix, Fionnuala Ni Aolain, and Jessica Clarke. The paper benefitted from being presented at Martha FIneman's Feminist Legal Theory Workshop at Emory and the Moral, Political, Legal, Social (MPLS) Theory workshop at the University of Minnesota and at the Law and Society 2014 Annual Meeting.

\section{REFERENCES}

Alford, J. R., Funk, C. L., \& Hibbing, J. R. (2005). Are political orientations genetically transmitted? American Political Science Review, 99(2), 153-167.

Amato, P. R., Booth, A., Johnson, D. R., \& Rogers, S. J. (2007). Alone together: How marriage in America is changing. Boston: Harvard University Press.

American Association of University Women. (2013). The simple truth about the gender pay gap. Retrieved from http://www.aauw.org/files/2013/03/the-simple-truth-about-the-gender-pay-gap-2013.pdf

Angrist, J. (2002). How do sex ratios affect marriage and labor markets? Evidence from America's second generation. Ouarterlv Journal of Economics, 117(3), 997-1038.

Banks, R. R. (2011). Is marriage for white people? How the African American marriage decline affects everyone. New York, NY: Penguin Group. 
Bart, C., \& McQueen, G. (2013). Why women make better directors. International Journal of Business Governance and Ethics, 8(1), 93-99. Retrieved from http://www.boarddiversity.ca/sites/default/files/IJBGE8-Paper5-Why-Women-Make-Better-Directors.pdf

Bartels, L. M. (2008). Unequal democracy: The political economy of the new gilded age. Princeton, NJ: Princeton University Press.

Bartlett, K. T. (1990). Feminist legal methods. Harvard Law Review, 103, 829-887.

Bass, F. (2012). Shining shoes best way Wall Street women outearn men. Bloomberg. Retrieved from http://www.bloomberg.com/news/2012-03-16/shining-shoes-best-waywall-street-women-outearn-men.html

Baum, N. (2007). Separation guilt in women who initiate divorce. Clinical Social Work, 35(1), $47-55$.

Becker, M. (1999). Patriarchy and inequality: Towards a substantive feminism. University of Chicago Legal Forum, 1999, 21-88.

Belsie, L. (2012). The causes of rising income inequality. National Bureau of Economic Research. Retrieved from http://www.nber.org/digest/dec08/w13982.html

Bennhold, K. (2013). The price of equality: Alison wolf's 'xx factor. The New York Times. Retrieved from http://www.nytimes.com/2013/10/06/books/review/alison-wolfs-xx-factor.html?pagewanted=all

Bertrand, M., Goldin, C., \& Katz, L. F. (2008). Dynamics of the gender gap for young professionals in the financial and corporate sectors. Retrieved from http://fairmodel.econ.yale. edu/ec483/katz.pdf

Bertrand, M., Kamenica, E., \& Pan, J. (2013). Gender identity and relative income within households Retrieved from http://faculty.chicagobooth.edu/emir.kamenica/documents/identity.pdf

Bianchi, S. (2011). Changing families, changing workplaces. Future of Children, 21(2), 15-36.

Bivens, J., \& Mishel, L. (2013). The pay of corporate executives and financial professionals as evidence of rents in top 1 percent incomes. Journal of Economic Perspectives, 27(3), 57-77. Retrieved from http://www.epi.org/publication/pay-corporate-executives-financial-professionals/

Brinig, M. F., \& Allen, D. W. (2000). These boots are made for walking: Why most divorce filers are women. American Law and Economics Review, 2(1), 126-169.

Brown, P., \& Cook, S. T. (Eds.). (2012). Children's placement arrangements in divorce and paternity cases in Wisconsin (Rev. Ed.). Institute for Research on Poverty. Retrieved from http://www.irp.wisc.edu/research/childsup/cspolicy/pdfs/2009-11/Task4A_CS_0911_Final_revi2012.pdf

Carbone, J., \& Cahn, N. (2013a). Casualty of the one percent. New York Times. Retrieved from http://www.nytimes.com/roomfordebate/2013/03/31/why-has-salary-parity-still-nothappened/gender-equality-is-a-casualty-of-the-one-percent

Carbone, J., \& Cahn, N. (2013b). The triple system of family law. 2013 Mich. St. L. Rev. 1185-1229. Retrieved from http://scholarship.law.umn.edu/faculty_articles/203

Carbone, J., \& Cahn, N. (2014). Marriage markets: How inequality is remaking the American family. New York, NY: Oxford University Press.

Cohen, P. (2013). College graduates marry other college graduates most of the time. The Atlantic. Retrieved from http://www.theatlantic.com/sexes/archive/2013/04/collegegraduates-marry-other-college-graduates-most-of-the-time/274654/

Cohen, P. N. (2010). Young, educated, and gender-gapped. Family inequality blog. Retrieved from http://familyinequality.wordpress.com/2010/07/23/young-educated-and-gapped 
Dallas, L. L. (2012). Short-termism, the financial crisis, and corporate governance. Journal of Corporation Law, 37(2), 265-364.

Desai, S., \& Johnson, K. (2005). Women's decisionmaking and child health: Familial and social hierarchies. In S. Kushor (Ed.), A Focus on Gender: Collected Papers on Gender Using DHS Data. Calverton, MD: ORC Macro. Retrieved from http://www.measuredhs.com/pubs/pdf/OD32/4.pdf

DiPrete, T. A., \& Buchman, C. (2013). The rise of women: The growing gender gap in education and what it means for American schools. New York, NY: Russell Sage Foundation.

Dokoupil, T. (2010). Lifestyle: Laid-off men don't do dishes. Newsweek. Retrieved from http://www.newsweek.com/lifestyle-laid-men-dont-do-dishes-82201

Dowd, N. E. (2008). Masculinities and feminist legal theory. Wisconsin Journal of Law, Gender and Society, 23(2), 201-248.

Dowd, N. E. (2010a). Asking the man question: Masculinities analysis and feminist theory. Harvard Journal of Law and Gender, 33(2), 415-430.

Dowd, N. E. (2010b). The man question: Male subordination and privilege. New York, NY: New York University Press.

Dubois, E. C., Dunlap, M. C., Gilligan, C. J., MacKinnon, C. A., \& Menkel-Meadow, C. J. (1985). Feminist discourse, moral values and the law-a conversation. Buffalo Law Review, 34(11), 11-88.

Eagly, A., Tanenbaum, L., Barsh, J., Pinker, S., Powell, G. N., \& Meers, S. (2009). Do women make better bosses? New York Times. Retrieved from http://roomfordebate.blogs. nytimes.com/2009/08/02/do-women-make-better-bosses/?_r=0\#alice

Eagly, A. H. (2013). Women as leaders: Leadership style vs. leaders' values and attitudes. Harvard Business School research symposium, gender \& work: Challenging conventional wisdom. Retrieved from http://www.hbs.edu/faculty/conferences/2013-w50-researchsymposium/Documents/eagly.pdf

Edin, K., \& Nelson, T. J. (2013). Doing the best I can: Fatherhood in the inner city. Berkeley, CA: University of California Press.

Eichler, A. (2012). Gender wage gap is higher on Wall Street than anywhere else. Huffington Post. Retrieved from http://www.huffingtonpost.com/2012/03/19/gender-wage-gapwall-street_n_1362878.html

Eichner, M. (2001). On postmodernist feminist legal theory. Harvard Civil Rights-Civil Liberties Law Review, 36, 1-77.

Eichner, M. (2010). The supportive state: Families, government, and America's political ideals. New York, NY: Oxford University Press.

Fineman, M. A. (2010). The vulnerable subject and the responsive state. Emory Law Journal, 60(2), 251-276.

Flom, B. M., \& Scharf, S. A. (2011). Report of the 2011 NAWL Survey on the retention and promotion of women in law firms. Retrieved from http://nawl.timberlakepublishing.com/ files/NAWL \%202011\%20Annual\%20Survey\%20Report\%20FINAL\%20Publicationready $\% 2011-9-11 . p d f$

Fukuyama, F. (1992). The end of history and the last man. New York, NY: Avon Books.

Gabaldon, T. A. (2013). The role of competitive disclosure in preventing the abuse of financial consumers. Banking and Financial Services Policy Report, 32(11), 17-30.

Glynn, S. J. (2012). The new breadwinners: 2010 update. Center for American Progress. Retrieved from http://www.americanprogress.org/issues/labor/report/2012/04/16/11377/ the-new-breadwinners-2010-update/ 
Goldin, C. (2014). A grand gender convergence: Its last chapter. American Economic Review, 104(4), 1-30.

Goldin, C., \& Margo, R. A. (1992). The great compression: The U.S. wage structure at midcentury. Ouarterly Journal of Economics, 107(1), 1-34.

Greenstone, M., \& Looney, A. (2012). The marriage gap: The impact of economic and technological change on marriage rates. Brookings. Retrieved from http://www.brookings.edu/ up-front/posts/2012/02/03-jobs-greenstone-looney

Guttentag, M., \& Secord, P. F. (1983). Too many women? The sex ratio question. Beverly Hills, CA: Sage.

Hacker, J. S., \& Pierson, P. (2010). Winner-take-all politics: How Washington made the rich richer - And turned its back on the middle class. New York, NY: Simon and Schuster Paperbacks.

Harris, A. (1990). Race and essentialism in feminist legal theory. Stanford Law Review, 42(3), $581-616$.

Hayes, C. (2012). Twilight of the elites: America after meritocracy. New York, NY: Broadway Paperbacks.

Hooda, S. (2012, updated). Unemployment rates highest amongst black and latinos. Huffington Post. Retrieved from http://www.huffingtonpost.com/2012/09/10/unemployment-rates-highest-amongst-black-and-latinos_n_1871453.html

Infoplease. (1990-2010). Median level of income, by level of education. Retrieved from http:// www.infoplease.com/ipa/A0883617.html\#ixzz1JFxpOxL9

Johnson, A. G. (2007). The gender knot: Unraveling our patriarchal legacy. Philadelphia, PA: Temple University Press.

Jost, J. T. (2006). The end of the end of ideology. American Psvchologist, 61(7), 651-670.

Joy, L., Carter, N. M., Wagener, H. M., \& Narayanan, S. (2007). The bottom line: Corporate performance and women's representation on boards. Catalyst. Retrieved from http:// www.catalyst.org/knowledge/bottom-line-corporate-performance-and-womens-representation-boards

Kalleberg, A. (2011). Good Jobs, bad jobs: The rise of polarized and precarious employment systems in the United States, 1970's to 2000's. New York, NY: Russell Sage Foundation.

Kaplan, S. N., \& Minton, B. A. (2008). How has CEO turnover changed? Retrieved from http://faculty.chicagobooth.edu/steven.kaplan/research/km.pdf

Kelly, M. G. E. (2009). The political philosophy of Michel Foucault. New York, NY: Routledge.

King, J. E. (2010). Gender equity in higher education: 2010. Washington, DC: American Council on Education.

Kristof, N. D., \& WuDunn, S. (2009). Half the sky: Turning oppression into opportunity for women worldwide. New York, NY: Vintage Books.

Lioz, A. (2013). Breaking the vicious cycle: How the supreme court helped create the inequality era and why a new jurisprudence must lead us out. Seton Hall Law Review, 43(4), 1227-1282. Retrieved from http://scholarship.shu.edu/cgi/viewcontent.cgi?article= $1484 \&$ context $=$ shlr

Lipsitz, R. (2013). Look, Ma! No Progress! Catalyst. Retrieved from http://www.catalyst.org/ blog/catalyzing/look-ma-no-progress

Lo Sasso, A. T., Richards, M. R., Chou, C. F., \& Gerber, S. E. (2011). The \$16,819 pay gap for newly trained physicians: The unexplained trend of men earning more than women. Health Affairs, 30(2), 193-201. 
Lublin, J. S. (2005, updated). The serial CEO. Wall Street Journal. Retrieved from http:// online.wsj.com/news/articles/SB1 12709114986644489

Marklein, M. B. (2005). College gender gap widens: 57\% are women. USA Today. Retrieved from http://usatoday30.usatoday.com/news/education/2005-10-19-male-college-cover_ x.htm

Mason, A. D., \& King, E. M. (2001). Engendering development through gender equality in rights, resources, and voices. The World Bank. Retrieved from http://documents.worldbank.org/curated/en/2000/10/828395/engendering-development-through-gender-equality-rights-resources-voices-summary

McClain, L. (2006). The place of families: Fostering capacity, equality and responsibility.cambridge. Cambridge, MA: Harvard University Press.

McLanahan, S. (2004). Diverging destinies: How children are faring under the second demographic transition. Demography, 41(4), 607-627.

Mechoulan, S. (2011). The external effects of black-male incarceration on black females. Journal of Labor Economics, 29(1), 1-35.

Mishel, L., Bernstein, J., \& Allegretto, S. (2007). The state of working America 2006/2007. Ithaca, NY: ILR Press. Retrieved from http://digitalcommons.ilr.cornell.edu/cgi/viewcontent.cgi?article $=1027 \&$ context $=$ books

Mishel, L., \& Finio, N. (2013). Earnings of the top 1.0 percent rebound strongly in the recovery. Economic Policy Institute. Retrieved from http://www.epi.org/publication/ib347-earnings-top-one-percent-rebound-strongly/

Mishel, L., \& Sabadish, N. (2012). CEO pay and the top 1\%. Economic Policy Institute. Retrieved from http://www.epi.org/publication/ib331-ceo-pay-top-1-percent/

Mundy, L. (2012). The richer sex: How the new majority of female breadwinners is transforming our culture. New York, NY: Free Press.

Murray, C. (2012). Coming apart: The state of white America, 1960-2010. New York, NY: Crown Forum.

Musick, J., Brand, J. E., \& Davis, D. (2012). Variation in the relationship between education and marriage: Marriage market mismatch? Journal of Marriage and the Familv, 74(1), 53-69.

Ni Aolain, F., Hayes, D. F., \& Cahn, N. (2011). On the frontlines: Gender, war, and the postconflict process. New York, NY: Oxford University Press.

Noah, T. (2010). The United States of Inequality. Slate. Retrieved from http://www.slate.com/ articles/news_and_politics/the_great_divergence/features/2010/the_united_states_of_ inequality/introducing_the_great_divergence.html

Noah, T. (2012). The great divergence: America's growing inequality crisis and what we can do about it. New York, NY: Bloomsbury Press.

Ny, R. (2013). Equal pay for women: Women still trailing behind despite higher education. Nerd Scholar. Retrieved from http://www.nerdwallet.com/blog/nerdscholar/2013/equalpay-women/

OECD. (2010). Investing in women and girls: The breakthrough strategy for achieving all the MDGs. Retrieved from http://www.oecd.org/dac/gender-development/45704694.pdf

Okin, S. M. (1989). Justice, gender and the family. New York, NY: Basic Books.

Page, B. I., Bartels, L. M., \& Seawright, J. (2013). Democracy and the policy preferences of wealthy Americans. Perspectives in Politics, 11(1), 51-73. 
Pew Research Center for People and the Press. (2012). Section two: Demographics and American values. Retrieved from http://www.people-press.org/2012/06/04/section-2demographics-and-american-values/6-4-12-v-32/

Piketty, T. (2014). Capital in the twentv-first centurv. Cambridge, MA: The Belknap Press of Harvard University Press.

Rattner, M. (2012). The rich get even richer. New York Times. Retrieved from http://www. nytimes.com/2012/03/26/opinion/the-rich-get-even-richer.html

Reardon, S. F. (2011). The widening achievement gap between the rich and the poor: New evidence and possible explanations. In G. J. Duncan \& R. J. Murnane (Eds.), Whither opportunity? Rising inequality, schools, and children's life chances. New York, NY: Russell Sage Foundation.Retrieved from http://cepa.stanford.edu/sites/default/files/ reardon $\% 20$ whither $\% 20$ opportunity $\% 20-\% 20$ chapter $\% 205$.pdf

Regenerus, M., \& Uecker, J. (2011). Premarital sex in America: How young Americans meet, mate, and think about marrying. New York, NY: Oxford University Press.

Rendall, M. (2011). The service sector and female market work: Europe vs US. Retrieved from https://editorialexpress.com/cgi-bin/conference/download.cgi?db_name=res2012\& paper_id $=1000$

Rorty, R. (1998). Achieving our country: Leftist thought in twentieth-century America. Cambridge, MA: Harvard University Press.

Rosin, H. (2012). The end of men and the rise of women. New York, NY: Penguin Press.

Sandberg, S. (2013). Lean in: Women, work, and the will to lead. New York, NY: Alfred A. Knopf.

Schwabish, J. A., \& Topoleski, J. H. (2013). Modeling individual earnings in cbo's long-term microsimulation model. Congressional Budget Office. Retrieved from http://www.cbo. gov/sites/default/files/cbofiles/attachments/44306_CBOLT.pdf

Shipman, C., \& Kay, K. (2009). Women will rule business. Time. Retrieved from http:// content.time.com/time/specials/packages/article/0,28804,1898024_1898023_1898078,00. $\mathrm{html}$

Sidanius, J., \& Pratto, F. (1999). Social dominance: An intergroup theorv of Social Hierarchy and Oppression. Cambridge: Cambridge University Press.

Slaughter, A. (2012). Why women still can't have it all. The Atlantic. Retrieved from http://www.theatlantic.com/magazine/archive/2012/07/why-women-still-cant-have-it-all/ $309020 /$

Smith, L. C., Ramakrishnan, U., Ndiaye, A., Haddad, L., \& Martorell, R. (2003). The importance of women's status for child nutrition in developing countries. International Food Policy Research Institute. Retrieved from http://www.ifpri.org/sites/default/files/publications/rr131.pdf

Soares, R., Bonaparte, S., Campbell, S., Margolin, V., \& Spencer, J. (2012). 2012 catalyst census: Fortune 500 women executive officers and top earners. Catalyst. Retrieved from http://www.catalyst.org/knowledge/2012-catalyst-census-fortune-500-women-executiveofficers-and-top-earners

South, S. J., \& Trent, K. (1988). Sex ratios and women's roles: A cross-national analysis. American Journal of Sociology, 93(5), 1069-1115.

Stanford News Service. (1996). The gender gap in politics goes deeper than a liberal-conservative split. Retrieved from http://news.stanford.edu/pr/96/961030gendergap.html 
Stevenson, B., \& Wolfers, J. (2006). Bargaining in the shadow of the law: Divorce laws and family distress. Quarterly Journal of Economics, 121(1), 267-288.

Stiglitz, J. E. (2012). The price of inequality: How today's divided society endangers our future. New York, NY: W.W. Norton \& Company.

Stiglitz, J. E. (2013). In no one we trust. New York Times. Retrieved from http://opinionator. blogs.nytimes.com/2013/12/21/in-no-one-we-trust/?_r=0

Stone, E. A., Shackelford, T. K., \& Buss, D. M. (2007). Sex ratio and mate preferences: A cross-cultural investigation. European Journal of Social Psvchologv, 37(2), 288-296.

Tankersley, J. (2013). Shift to a service-drive economy delays job recovery. Washington Post. Retrieved from http://www.washingtonpost.com/business/economy/shift-to-servicesdelays-job-recovery/2013/05/03/a78ec0f0-b3f3-11e2-9a98-4be1688d7d84_story.html? wprss $=$ rss_business

Testy, K. Y. (2000). Adding value(s) to corporate law: An agenda for reform. Georgia Law Review, 34(2), 1025-1048.

Unicef. (2007). The state of the world's children 2007: Full report. Retrieved from http://www. unicef.org/sowc07/report/report.php

U.S. Census Bureau. (2009). PINC-03. Educational attainment - People 25 years old and over, by total money earnings in 2008, work experience in 2008, age, race, hispanic origin, and sex. Retrieved from http://www.census.gov/hhes/www/cpstables/032009/perinc/new03_ 175.htm

West, R. (1999). Caring for justice. New York, NY: NYU Press.

West, R. (2011). Tragic rights: The rights critique in the age of obama. William \& Mary Law Review, 53, 713-746.

Wilcox, W. B., \& Marquardt, E. (Eds.). (2010). When marriage disappears: The new middle America. National Marriage Project and Institute for American Values. Retrieved from http://stateofourunions.org/2010/SOOU2010.pdf

Wilkinson, R., \& Pickett, K. (2009). The spirit level: Why greater inequality makes societies stronger. New York, NY: Bloomsberg Press.

Williams, J. C. (2010). Reshaping the work-family debate: Why men and class matter. Cambridge, MA: Harvard University Press.

Williams, J. C., \& Boushey, H. (2010). The three faces of work-family conflict: The poor, the professionals, and the missing middle. Center for American Progress. Retrieved from http://www.worklifelaw.org/pubs/ThreeFacesofWork-FamilyConflict.pdf

Wolf, A. (2013). The XX factor: How the rise of working women has created a far less equal world. New York, NY: Crown Publishing Group. 